hardly need to be surprised. First, there is the systematic playing down of animal altruism: " $[\mathrm{t}]$ he essential virtuousness of human beings is proved not by parallels in the animal kingdom, but by the very lack of convincing animal parallels". We are urged not to bowdlerize nature by playing up the slimmest of clues to animal virtue - as if, ever since Konrad Lorenz and Robert Ardrey, the literature on animal behaviour has done exactly the opposite: that is, overemphasized the competitive and aggressive side. The postulated discontinuity between humans and animals serves to position morality as a recent advance. In this, the author follows a tradition going back to Thomas Henry Huxley's "Evolution and Ethics" lecture in 1893, which granted morality only the shallowest of roots in human nature.

Second, the book stresses that selfishness is in our genes, and that genes are our masters. Time and again, we receive seemingly contradictory explanations about the selfishness of genes versus the occasional unselfishness of the behaviour that these genes produce. Of course, every biologist believes that behaviour evolved because of the benefits associated with it, but it is essential to realize that for terms such as 'selfishness' or 'unselfishness' to have any meaning at all, behavioural effects ought to be recognizable to the actors, not just to evolutionary biologists. Most animal behaviour even human, is poorly categorized along this dimension.

Ironically, a teleological position left behind long ago with regard to the evolution of species has now achieved popularity with regard to genes. What the selfish-gene metaphor has done is infuse the evolutionary process with direction and intent. Genes are said to be in charge, and to strive for their own reproduction. But really all that is going on is that genes - a mere batch of molecules - replicate at different rates dependent on the traits they produce. Rather than doing the selecting themselves, they are being selected. As soon as the idea that they have a goal in life is abandoned, the paradox that Ridley tries to resolve evaporates before our eyes.

This critical reflection is absent, however. The Origins of Virtue reads like a conflation between the nonexistent psychology of genes and the actual psychology of individuals. Virtue can be found in the constructs of human sociality, such as the marketplace or bonds of trust, but is absent from the hearts and souls of people. No doubt some readers will agree with this view, but the book can also be read as a testimony to the outlived usefulness of yet another metaphor.

Frans B. M. de Waal is at the Yerkes Regional Primate Research Center and the Department of Psychology, Emory University, Atlanta, Georgia 30322, USA.

\section{How the camel got his hump}

\section{Juliet Clutton-Brock}

A Perfect Harmony. By Roger A. Caras. Simon and Schuster: 1996. Pp. 271. $\$ 23$.

THE behavioural and cultural changes brought about in animals by domestication have been a neglected area of study. This is in great part because domestic animals have been considered to be artefacts of human culture and therefore outside nature. But views are changing and the biological adaptations that have enabled certain species of animals to flourish in human societies can be seen to result from the same evolutionary process that produced the human species.

With the knowledge that there have been anthropogenic influences altering environments for upwards of 70,000 years, it is becoming meaningless to talk of wilderness areas. Soon, the necessity to manage wildlife will mean that the wild will merge with the tame. For this management to be successful, it is becoming imperative to study the interactions of humans and animals as they were in the past and to consider how they should be in the future.

Ethology, the study of animal behaviour, joined what New Scientist magazine recently called "the pantheon of 'true' sciences" in the 1960s. Archaeozoology, the study of animal remains from archaeological sites, providing evidence for the history of domestication, joined in the 1970 s.

Anthrozoology, the study of interactions between humans and animals, is still struggling to push its way in, and recognition by the scientific community has been slow. This is despite the launch of a journal, Anthrozoös (reviewed in Nature 341, $364 ; 1989)$, and the foundation of the International Society of Anthrozoology, which this year held a successful international conference in Cambridge, England.

Research in anthrozoology is burgeoning in the United States, with authoritative publications by the likes of Harriet Ritvo, Andrew Rowan and James Serpell. None of these authors is cited in $A$ Perfect Harmony, which is not intended to be a report of recent research but is mostly an account of the author's personal views of the impact of animals on the history of civilization. Roger Caras is clearly most at ease when recounting anecdotes. These provide some intriguing bits of information, such as how the word 'trivia' - Latin for the junction of three roads - became associated with 'gossip'. This was because people met and gossiped at the markets traditionally held at such junctions.

Caras is not so happy with the dry bones of fossil history and sometimes he goes hopelessly awry, for example where he writes: "Some Stone Age cultures without domestication did blossom, but they were quick and lonely affairs, like unseen firework displays. The world and all history were untouched by them." The book is, alas, full of misinformation of this kind, for, after all, the Palaeolithic period lasted around 100,000 years and in Europe it ended only some 12,000 years ago.

Caras claims that the ancestral species of domestic cattle has not been identified in fossil form in Europe. This is a strange comment, as the remains of Bos primigenius (known to be the ancestor of all taurine cattle) are commonly found on sites throughout the Palaearctic region.

Apart from these idiosyncratic interpretations, much of the known history of domestic animals is well summarized and interspersed with informative comments on every aspect of past and present interactions between humans and animals. The book is illustrated with charming drawings and has a foreword by the great futurist and friend of the author, Arthur C. Clarke.

It has to be said, however, that $A$ Perfect Harmony is a peculiar title for a book about the exploitation of animals which have often suffered, and still suffer, great cruelty. Harmony is a concept that is surely quite alien to most relationships between humans and animals, but presumably it is the author's hope for the future, as in the Breughel painting of "Earthly Paradise" reproduced on the book's jacket.

The recognition that domestic animals are as worthy of study as wild species and discussions now being widely held on consciousness in animals owe much to the animal-welfare movement. It is therefore rather surprising that Caras, who is president of the American Society for the Prevention of Cruelty to Animals, does not have more to say about these topics. The inappropriate and often cruel management of farm animals is mentioned in an afterword, but surely there should have been a serious discussion of the animal as an individual and of the ethics of intensive farming.

Because it is very readable, $A$ Perfect Harmony may join Stephen Budiansky's The Covenant of the Wild (Morrow, New York, 1992 - for a review see Nature 356, $487 ; 1992)$ as a popular and much discussed book, but neither should be read as an authoritative text.

Juliet Clutton-Brock, editor of the Journal of Zoology, lives at South Barn, High Street, Fen Ditton, Cambridge CB5 8ST, UK.

In the Company of Animals: A Study of Human-Animal Relationships by James Serpell is now out in paperback. Cambridge University Press, $£ 7.95$, $\$ 11.95$. 